Article

\title{
Teachers' Transgressive Pedagogical Practices in Context: Ecology, Politics, and Social Change
}

\author{
Antonia Condeza-Marmentini *(D) and Luis Flores-González * \\ Faculty of Education, Pontificia Universidad Católica de Chile, Santiago 6904411, Chile \\ * Correspondence: aqcondez@uc.cl (A.C.-M.); lmflores@uc.cl (L.F.-G.); \\ Tel.: +56-9-92362178 (A.C.-M.); +56-2-223547937 (L.F.-G.)
}

Received: 26 June 2019; Accepted: 13 October 2019; Published: 4 November 2019

check for updates

\begin{abstract}
Chilean teachers face the urgent challenge of incorporating environmental and sustainability dimensions into their teaching practices within an economic and social context of extreme neoliberalism, which has an important impact on both teaching practices and hegemonic perspectives on the environment. Therefore, this article explores the motivations that guide the environment-related practices of teachers at Chilean secondary schools. Using a framework of pragmatism and phenomenology, it addresses teachers' meaning-making through the interpretative axes of their views on the environment and theories of education, addressing the following categories: (1) connection and consciousness; (2) participation and politics; and (3) re-thinking education. The discussion emphasizes the importance of understanding "environmental issues" in context, together with the transversal axis of social change. Teachers' meaning-making arises from their social and historical context and can be interpreted from the standpoint of traditions of thought originating in Latin America. The article argues that the transgressive element in the studied practices is social change, understood as community action arising from a combination of critical reflection and with an emphasis on the co-production of knowledge in this collective sphere. This is experienced by the teachers as a challenge to their capacity to address the inherent uncertainty of knowledge and the projection of a utopian society as a social right.
\end{abstract}

Keywords: environmental and sustainability education; social change; transgressive learning; teachers; Chile

\section{Introduction}

Today, we face the urgent goal of making radical changes in the way we live and inhabit the world. As human beings we share this goal and seek to address the "environmental crisis" from different perspectives that give meaning to our actions and help in dealing with their complexity. From this standpoint, there are pending challenges of configuring community understanding of the environment and the crisis, giving meaning to different perspectives on the problem, and opening paths for action.

Within this framework, one of the important questions in this historic moment is how to re-think education so that it can contribute to addressing uncertain future challenges [1]. This paper argues that this process is related to meaning-making at the subjective level, and in the dynamic interactions between this level and other decisive processes in knowledge configurations [2].

From an environmental education perspective, this crisis has been linked to traditional educational perspectives developed and implemented around the world in recent centuries. [3]. In the face of the current socio-environmental crisis, the role of education is, therefore, key to addressing the necessary changes, and the field of education faces the enormous challenge of joint reflection in order to offer multiple alternatives to face this crisis. However, the urgency of the crisis means that some approaches to environment-related education have distanced themselves from the basic questions of education 
and its purposes and aims [4-6]. The attention given to this distancing is important at all levels, but particularly as a framework for investigating contextualized educational practices in which these fields show different values and meanings.

Along with other aspects, such as interdisciplinary approaches, contextualization has been shown to be key in addressing the crisis from different perspectives [7-14]. In the field of environmental education, the existence of different cultural perspectives on the environment-education relationship along with the difficulties of intercultural dialogue are recognized [15-17]. There has, however, been a lack of proposals that facilitate understanding and appreciation of the differences as part of the construction of a framework that also permits observation of the dynamics of interaction and construction of knowledge and action in specific contexts.

Research on environmental education in Chile is a virtually unexplored field [18] and offers few findings that allow comparison of pedagogical practices with relevant frameworks in the regional context. Therefore, we draw on those theories and practices that define the region's identity, which although extremely diverse, have shared cultural and historical roots, especially with respect to reactions to domination, albeit these are interwoven differently in each context. In Chile, the "peripheral" context seems crucial in recognizing the different configurations that the environment and education take in the face of everyday problems, contributing different perspectives, either in terms of the configuration of "environmental problems" or the ways in which they can be addressed from an educational standpoint.

Regarding environmental education in the Latin American context, González-Gaudiano [19] argues that it has been characterized by an extraordinarily eclectic mixture of pedagogical and political traditions. In this research, we seek to understand this mixture in greater depth, referring to some of the region's traditions of environmental and pedagogical thought and highlighting the context as key to thinking about practices as transformative and transgressional actions.

Recent research in the field of environmental education has introduced the concept of disruption as a desirable competence in relation to transgressive learning [20,21]. From an emplaced perspective, the transgression required to advance towards a sustainable future must be evaluated in light of the contexts in which each educational practice is developed, considering aspects already highlighted by research in the field, such as the meanings of "the environment", depending on each particular context [2]; the repercussions of over-emphasis of expected outcomes as "products" of learning [22-25] and the tendency to promote normative perspectives; the tension between hegemonic discourses and local perspectives and their evolution; and other aspects that can influence educational practices and are not necessarily apparent to the members of educational communities.

From this perspective, transgressive learning takes place in a certain context, and is made possible by the same intersubjective configuration of knowledge, which, when understood from the standpoint of a participatory epistemology, is in itself a transgressive form that seeks to understand learning as embodied in human action and interactions.

Within this framework, this article highlights the first-person experience of teachers who, more or less in isolation, face the constant challenge of incorporating the environment into their teaching practices. Faced with the need to adjust their own structures of knowledge and pedagogical action [26], their experiences, perceptions, and values regarding the environment and nature, together with their purposes in the field of education, play a key role in the development of their teaching practices [26-33]. Teachers' practices are considered part of a tapestry of both social and historical knowledge [34] and are interpreted from the standpoint of the urgent need for disruptive change in the particular "rules of the game" of each cultural context. By drawing attention to the teachers' intentions in addressing environmental issues, it is possible to contribute to both reflection about their practices [28] and recognition of first-person perspectives as fundamental aspects in the construction of proposals that address environmental issues in context, taking into account their educational dimension.

This article is divided into five parts. It begins by setting out some perspectives related to teachers' margins of action and agency in different research contexts. In addition, it describes some characteristics of the fields of education and the environment in Chile in recent decades in a bid to 
provide a background to the interpretative framework of the research. Secondly, it discusses the frameworks of pragmatism and phenomenology as the main theories, followed by the characteristics of the research method. It then goes on to present the findings and the teachers' long-term purposes in the categories of "connection and consciousness", "participation and politics", and "re-thinking education". In the fourth section, these categories are discussed in relation to the transversal axis of social change, some of the influences in the Latin American context and their transgressive dimension. The last section examines some aspects related to the co-implication between the teachers' perspectives on the environment and education and those promoted by the public policy approach to Education for Sustainable Development (ESD).

\subsection{Teachers, Education, and the Environment}

This section reviews the findings of published research, undertaken in different contexts, that seeks to understand teachers' perspectives on environmental education. These studies address the question of teachers' agency and interpretative spaces.

In relation to teachers' agency, Biesta [35] argues that there is tension between stances that foster teachers' control over their work and those that seek to reduce opportunities for exercising this control. Agency can be viewed as a weakness that must be limited by the evidence or as a key component of education with meaning [2]. Research on environmental education has highlighted teachers' agency as a desirable element. However, the research differs on teachers' adherence to political frameworks that can be considered activism [36].

Based on the review of the literature, research on teachers of environmental education can be divided into that of the North, which focuses on the opportunities and restrictions of the general framework of Education for Sustainable Development (ESD), and that carried out in the South, which highlights the interweaving of different perspectives on the environment and education and their tensions with respect to approaches as ESD. In this section, these groups are presented in relation to the spaces of possibility that emerge when interpreting the link between practices, approaches, and policies.

In the North, research has looked mainly at how teachers adapt to the challenges posed by the ESD approach and its conclusions highlight the difficulties that, personally or institutionally, they experience in seeking to achieve holistic, comprehensive or interdisciplinary approaches [30,37-41]. Several of these investigations have led to substantive criticism of the proposed framework. For example, the recent work of Aarnio-Linnanvuori [42] recognizes that a model of environmental responsibility focusing on individual actions would restrict the range of possibilities of action perceived by Finnish students. From another perspective, Nikel [30] and Hasslöf and Malmberg [43] suggest that the ESD approach, together with the ambiguities that sometimes surround it, would permit spaces for conceptualization and practice that favor the subjectivation of teachers and the emergence of critical thinking in both them and their students. Certainly, the ESD approach also differs in each specific context as regards its interpretation and related research, raising questions about its adaptation to a particular context.

The questions asked by researchers in countries of the South have focused on the interpretation of teaching experiences related to the environment as a first objective [33] and points of convergence between teachers' subjective perspectives and those of the ESD approach [44-47]. The results highlight important cultural differences, which imply tensions and co-adaptation between educational approaches and local cultures. In the Korean context, for example, Hwang [33] suggests that the interpretative spaces left by conceptual difficulties and the influence of discourses and hegemonic policies are fundamental for the development of emplaced perspectives related to relationships between environment and education.

In both the North and the South, post-structuralist research notes that national education agencies have incentives that could lead teachers to respond to ESD-related educational standards as "environmental managers", affecting the possibility of developing transformative perspectives [48,49]. 
By focusing on teachers in the first person, it is possible to learn about the ends for which they design their practices and the interests with which they address environmental issues. Through teachers' long-term purposes as the basis of their meaning-making, pedagogical intentions can be interpreted in context. This article also discusses the tension between these purposes and local political practices and frameworks, using an approach under which teachers are both products and producers of the place of which they form part.

\subsection{An Approach to the Chilean Neoliberal Context in the Framework of Education and the Environment}

The education system in Latin America has been described by González-Gaudiano as “ . . resistant to change, in addition to rigid, closed school structures, curricula that still focus on disciplines, and a teaching body uninterested in new approaches" [19] (p. 156). By creating barriers that can be considered to structure the system, this makes it very difficult to position environmental education at the formal level [50]. Environmental education, therefore, has developed largely on the periphery of formal education and has its origins mostly in the 1960s and principally in the work of non-governmental organizations (NGOs) [51], which sought to resolve social problems from the local level [52].

In Chile, despite the efforts of NGOs in local contexts, the development of environmental education has been particularly slow. During the country's long period of military dictatorship, it was difficult for citizens to call attention to local environmental problems in the context of a neoliberal model based on the export of raw materials [52]. This model meant that little importance was given to these early educational experiences [51], which are part of the historical and social knowledge that links the environment to education in this context.

Since the dictatorship, Chile's educational policies have, moreover, been characterized by a privatization model that resulted in a high level of social segregation and inequity in educational systems. In the 1990s, great emphasis was also placed on measurement and accountability [53]. As a result, educational standards were tied to regulation and produced new forms of restricted professionalization, confining teachers to a limited range of pedagogical models and curricula in order to comply with externally defined goals [54].

The effects of neoliberalism are also apparent in public policy on the environment. The restoration of democracy in 1990 was conditioned on the signing of the country's first international economic integration treaties, which included the introduction of its first laws on the environment [52] in a quest to regulate environmentally the production of commodities in the framework of neoliberal economic globalization. In 1994, the Law on the General Framework for the Environment (LGBMA) was introduced, defining environmental education as an "instrument of environmental management" [55] (p. 15).

Subsequently, between 2009 and 2011, social demand for quality and free education and opposition to large-scale extractive projects converged, as reflected in the mass protests that occurred in 2011. The National Policy on Education for Sustainable Development (PNEDS), launched in 2009, defined "sustainable development, fundamentally, as that which satisfies the needs of the present without compromising the ability of future generations to satisfy their proper needs" [55] (p. 9). Adapted from the Brundtland Report, this definition reveals an important lag with respect to the range of perspectives on sustainability and criticisms of the three-pillar model of sustainable development, along with the invisibilization of educational proposals suited to the Chilean context [51].

These particular conditions in Chile have delayed the development and dissemination of contextualized environmental and educational perspectives in the formal sphere, resulting in their replacement in the Chilean curriculum by a very limited approximation to ESD. In the case of formal education, "sustainability" is considered one of the transversal objectives that are constantly waiting for educational reforms to introduce new approaches [56]. González-Gaudiano [50] argues that the transversal way in which socio-environmental issues have been addressed has resulted in a lack of will and resources to incorporate the approach of sustainability as from the stage of initial teacher training. This has been recognized as one of the key barriers to the development of environmental education 
in Latin America [19]. A study in the south of Chile, for example, found that the training of the vast majority of primary and secondary schoolteachers had not included environmental education. Similarly, according to the study, "Diagnosis of Commitment to Sustainability in Chilean Universities" [57] only six universities, out of a total of 36 , had specific undergraduate courses related to the environment or sustainability. It was not clear from the study whether any of these were related to teacher training.

In the informal sphere, however, progress has been seen in environmental education as a result of empowerment in the face of environmental conflicts [19] and the analysis and social proposals developed in the region with a view to positioning Latin American thought regarding the construction of counterhegemonic perspectives on society and the environment. This has generated an interesting tension between institutional approaches and emerging practices. As a result, the different influences at work in configuring environmental education practices in Chile and Latin America and their lack of institutionalization constitute a "unique environmental education discursive framework ( ... ) which also has a much more clearly identifiable political component" [19] (pp. 159-160).

\section{Research Methodology}

\subsection{Theory: Convergence between Pragmatism and Phenomenology: Knowledge, Meanings, and Action}

This research has its theoretical basis in both the pragmatism of John Dewey and the phenomenology of Merleau-Ponty [58] and Francisco Varela [59]. These two frameworks have in common the idea of transcending the traditional division between subject and object. Both take experience as the basis of the configuration of knowledge, which is viewed as a structurally intersubjective relationship. In this sense, pragmatism and phenomenology converge in a conception of knowledge that also allows us to refer to it in a context, helping to interpret historically and culturally-emplaced pedagogical practices.

In the educational field, Dewey proposes educational practice as the main object of research and the educational practitioner as its central figure. Drawing on Dewey, this study seeks to understand teachers' meaning-making through their practices and these practices as decisions in the face of educational problems that are unique insofar as they require responses appropriate to their idiosyncrasy [60].

Pragmatism understands knowledge as reflection and action where encounters with the environment permit future actions in a process of meaning-making through their consequences. Knowledge is then primarily a property of behavior, through which objects are differentiated and transformed through transactions into events with meaning [61]. Contrary to the distinction made by the subject-object theory of knowledge, transactions are unfractured observations between "the observer, the observing, and the observed" [62] as a result of the creative and unpredictable modification of the suddenness of emergence of new objects, along with the self as emerging subject [63] (p. 87). Similarly, in phenomenology, knowledge comes from the interface between mind, society, and culture and does not pre-exist in any shape or place if not enacted in particular conditions. Placing cognition as corporatized action is enacting the world-making a world emerge-and success for a cognitive system is when it becomes part of an ongoing existing world or shapes a new one [64].

The fundamental contribution of phenomenology to this research is its proposal of intersubjective knowledge while that of pragmatism is its understanding of knowledge as meaning and action. Thus, meaning-making is not only the process by which the individual acquires knowledge through encounters and transactions for action. This knowledge is also first and always configured intersubjectively. Both qualities contribute to formulating knowledge as a social and historical network and highlight its emplacedness. The value of the educational experience lies not only in its potential at the level of the reflection of the individual and its own particularities, but also in the possibility of constructing a type of originative knowledge about the action of the world and looking towards the configuration of a new world and that of other possible worlds. 


\subsection{Method}

In this project, we worked with six secondary teachers from schools in the Santiago Metropolitan Region. They taught different subjects, but had all decided to include environmental issues in their classes or workshops.

They were selected through an online survey of members of the Network of Eco-Educators, an organization of schoolteachers related to environmental issues created by the Environment Ministry. A minimum period of experience with environmental issues was required for selection, along with interest in participating in the research. Importance was also given to ensuring a variety of disciplines. In a further effort to achieve the latter, teachers participating in the "Jovénes por el Clima" (Young People for the Climate) project, who also met the criteria, were invited to take part in the research. The environment-related educational actions were mostly designed by the teachers themselves in response to both educational policy and the curriculum and their views and interests as regards the environment and education.

At least two semi-structured interviews were carried out with each teacher in a bid to interpret their environmental education practices and the long-term purposes behind the content and teaching methods used [28]. Following Sund and Wickman [28], these "long-term purposes" correspond to the teachers' answers to questions about why it is important for students to learn about environmental issues. They are interpreted based on the arguments that teachers repeated in the description of their practices, repetitions that are considered dynamic patterns of action.

Categories of long-term purposes were defined in terms of teachers' answers to the question of their reasons for addressing environmental issues. They correspond to the matters to which they repeatedly return as the grounds for what it is relevant to teach students.

\subsection{Analysis and Interpretation}

The first phase of analysis involved the iterative reading of the interviews and the construction of categories of long-term purposes based on answers to the questions: "What do you want the students to learn in relation to environmental issues?" and "Why is it important for students to address environmental issues?" [28].

In a second phase, the categories were analyzed in relation to the various aspects of the practices investigated, with an emphasis on the variables that make them specific. Several authors have proposed addressing the multiplicity of variables that influence the configuration of different educational practices, including educational theories; the relationships between teachers and students; the relationships between the school and society; and environmental ethics [26,36,65-69]. Operationally, the dimensions of the environment and theories of education proposed by Sandell et al. were used as interpretative axes [66], along with other variants relevant to the analysis. Long-term purposes are described based on the dimensions of "environmental approaches and teaching methods" used within the framework of the production of "Selective Traditions of ESD" in the Swedish context [27]. "Environmental approaches" refer to how the character and scope of environmental problems are perceived, taking into account positioning regarding environmental politics. Teaching methods represent the role of the school in society.

The findings reveal different ways in which teachers pursue the purpose of social change. These are discussed as different forms of meaning-making and are interpreted based on some traditions of thought and action in Latin America, situating them in a specific context in relation to perspectives on the environment and education.

\section{Results}

Based on the analysis of the teachers' long-term purposes in including environmental issues in their practices, the following categories were identified: "connection and consciousness", "participation and politics" and "re-thinking education". Figures 1-3 show the contents of each category, which are also summarized in Table 1, with an emphasis on the key dimensions proposed by Sandell et al. [66]. 


\section{1. 'Connection and Consciousness'}

Two science teachers and one philosophy teacher, Nicanor, Diana, and Danissa, respectively, make up this category, which is characterized by two consecutive moments referred to by the teachers as "union with nature" and "process". These moments are described as two stages in a strategy to harness the perspective of the individual to the formulation of a collective vision in pursuit of the objective of social change. In this, the methods used may vary from a sensory approach to pluralistic pedagogical approaches that also open up opportunities for interdisciplinary collaboration.

The teachers express an understanding of nature as "our origin, to which we belong", with a sensory and experiential approach to teaching similar to that proposed by Kolb [70]. This method is geared to students' personal development which, fostered by consciousness of their intrinsic relationship with nature and the order it proposes, inspires the values of cooperation and promotes a change of attitude and conduct that is conducive to care for the environment.

This category's purpose of developing "integral human beings" calls for connection which, for Nicanor, has a spiritual component.

"...appreciation of nature, a deep connection with nature, being passionate about it, becoming conscious that what you are seeing is not external, but also part of you. I believe that is a quite spiritual component."

As indicated above, "connection and consciousness" involves two moments that may or may not be related to the students' stage of development. The first phase is the experience of "union with nature" (connection) which fosters a reorientation of the human being-nature relationship based on experience and knowledge of its patterns of operation, expressed mainly in the language of ecology and holism. The second phase corresponds to the "process" and alludes to students' path to decision-making in the face of different alternatives. At this point, critical reflection on environmental problems is important and students are expected to move towards an active-critical role. Both phases are reflected in Diana's words:

Interviewer: "What do you think it is important for students to learn about the environment?"

Diana: "On the environment, one can develop a lot of skills with the student that will be useful for developing your life as an integral being (...) a powerful formation in the sphere of values, in the sphere of conservation. (...). That student is going to behave in a friendly way towards the environment and is going to want to live in a much fairer society with more social justice."

(...)

Interviewer: "And what actions go 'beyond' as you mentioned?"

Diana: "It has to do with reflection; a child, however small, can be taught to reflect critically about the environment, and, on reaching maturity (...) has to have the capacity to think about why the environment is the way it is. What happens? (...) Then the child, or the young person, has to reach a stage where he or she definitively says 'Hey, there's a mess on the planet with the mechanisms of production, this capitalist system or whatever you want to call it. (...) It definitely makes inequity increase and precisely the segregated continue to be segregated (...) green areas are not distributed equally across different neighborhoods.'"

In the second phase, the approach to the environment in the teachers' practices is related to social justice or the "evolution of our society".

"... to break with certain cultural traditions (... ) and take a different view that is simple, humble, seeks equity and justice, looks at things in a different way (...) different types of leadership and that finally is a matter of consciousness and then it is more relevant to do what we do." (Nicanor) 
The objective of "forming conscious citizens, who can make their own decisions" is key in the construction of this category. The consequence is expressed both in relation to belonging to nature and the process of change of perspective with respect to cultural local traditions linked to equity. In the case of the transition from school to society, teachers ask themselves, "how can we wake children up to wanting to participate in environmental issues outside school?" From her perspective, Danissa recognizes that "what I have learned here leaves a mark on the more collective participation in the instances in which they will have access to participate."

From the collective possibility, teachers mark a distance from individual actions, projecting their purposes towards the community level, as reported by Diana:

"But let it be nature that makes you reflect and finally empowers you and makes you say 'look, I can collaborate with this action, I can activate here and connect with others because, ultimately, alone, it would only be activism.'" (Diana).

Regarding their own trajectories, teachers seek to promote forms of change through alternatives that foster plausible processes in the school sphere and give meaning to their projects for change in society.

"When I was at the academy, I was on the level of criticism and did not have the tools or practical methodologies to be able to find what the real change was going to be. For me, everything that has to do with ecology, with these changes of habits, with valuing ancestral traditions (...) I find that, in those moments, they make more sense. They are really educational experiences that can be replicated in schools, in universities." (Danissa).

In this framework, teachers are in a transition towards more participatory pedagogies, seeking alternatives to the traditional approach of teacher-centered planning. In the case of these practices, the reconfiguration of traditional science and ecology as regards environmental issues fosters a shift towards the possibility of interdisciplinary co-construction of meanings and knowledge.

"I have to see biogeochemical cycles, how boring! (...) As concepts, they are very dry. So we said, 'Let's see the cycles, but from the standpoint of environmental problems (...) together with language'." (Nicanor)

Through environmental issues, teachers seek to address difficult parts of the curriculum together with other subjects, opening up new alternatives in the traditional structure of knowledge and the school.

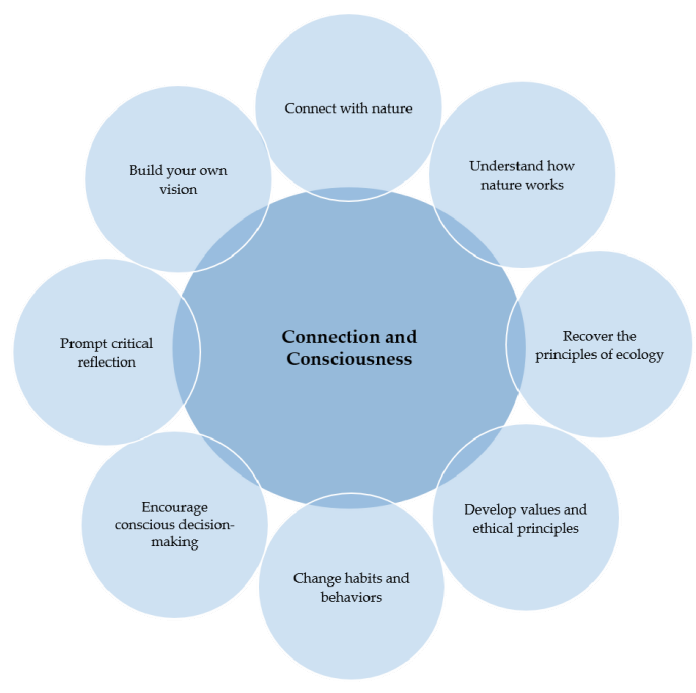

Figure 1. 'Connection and Consciousness'.

\section{2. 'Participation and Politics'}

Juan and Luis, social sciences teachers, have in common the long-term purpose of incorporating the environment into their pedagogical practices through "think, support, participate and build political positions". They understand politics as "the place of conflict between different sensitivities that coexist in a society". 
These teachers view environmental problems as inherent to the tension between lifestyles and the planet's limitations. The problems must, therefore, be addressed fundamentally through reflection and the practice of alternatives. Environmental issues, along with other current issues such as education, health, migration, and globalization, are treated as a decisive dimension of the process of "evaluating the surroundings in which we live", considering environmental issues as urgent and relevant for advancing in that construction.

In the quest for new perspectives to address the challenge of incorporating environmental issues, teachers draw on diverse approaches to finding meaning through reflection on their differences.

"Last year, I relied a lot on the proposals of ecology and sustainable development; it's easy to find material from the Ministry and in the literature. Obviously, the idea was to create consciousness (... ) in other words, care for water, electricity (...) and I tell them that these actions should be common sense by now, it's not as if we need to be saying it all the time. (...) I took that liberty because the school already has an eco-monitors program (... ) so I think that instance is already there." (Luis)

In this category, environmental issues are discussed with the aim of developing in students "new sensitivities, stances and commitments", based on empathy with those who suffer from tensions between the different perspectives on the use of finite natural resources. Emphasis is placed on the development of ethics and reflection about the criteria for interacting with others, which are accessed by "thinking and acting politically".

Interviewer: "How do you approach environmental issues?"

Juan: “... from the standpoint of participation and especially opinion, from what an individual can do to evaluate their surroundings and be able to say 'what do I do to contribute to generating my surroundings?' (...) I seek to form (...) students committed to a cause, really committed to a cause, regardless of whether that cause is purely environmentalist or may be of another type. (...) I always appeal to the capacity for organization, participation, and information."

The teachers highlight discussion, debate, and the methodology of projects as the central ways to address environmental problems, with the purpose of permitting the installation of environmental issues as "a new sensitivity", promoting daily actions and "changes in the criteria of common sense" of students, and seeking to create citizenship based on commitment to the organization and production of society. This method begins by identifying students' needs in a participatory manner in order to generate community projects. Regarding the methodology of projects, Juan notes that:

"They would be working with a syllabus that, in the first place, has to do with their interests. Second, they would be making use of a healthy democratic exercise within the school space. Third, it would no longer be exclusively the adult-centric approach of saying, 'Hey, I demand you learn this and I don't care what you want to learn; you have to learn this?'" (Juan)

Through this spontaneous description of its educational purposes linked to the environment, within the set of dimensions that configure the construction of the environment, the teacher explains his pedagogical practice as a series of challenges to the predominant educational structures in his context.

"This space seems strange to the students. (...) In this oasis, I can think and then not, it's weird for them and for me; I was very accustomed to working with the content of the curriculum (...) test, grades. (...) What I did at the beginning of this year was to leave a unit of topics proposed by them (...) This year, I left it for the end of the year because I realized that, by the end of the process, they were more accustomed and had more confidence to put forward ideas." (Luis)

In this category, the transition to more participatory methods is geared to the use of "topics" proposed by the students and fostering participation outside school. For Juan, the experience of participating in a local young people's town hall meeting is a challenging and open-ended experience: 
"We are going to register with the local Town Hall (...) with the idea of always trying to work with the clear idea of the assembly. I have tried to put a lot of emphasis on what an assembly or horizontality mean. (... ) I don't know what will come of this. I hope that only good things. But I don't know, I don't know."

The option of transcending the barriers of the school by taking on environmental responsibilities is key in this category, which rests on politics as a practice at the community level.

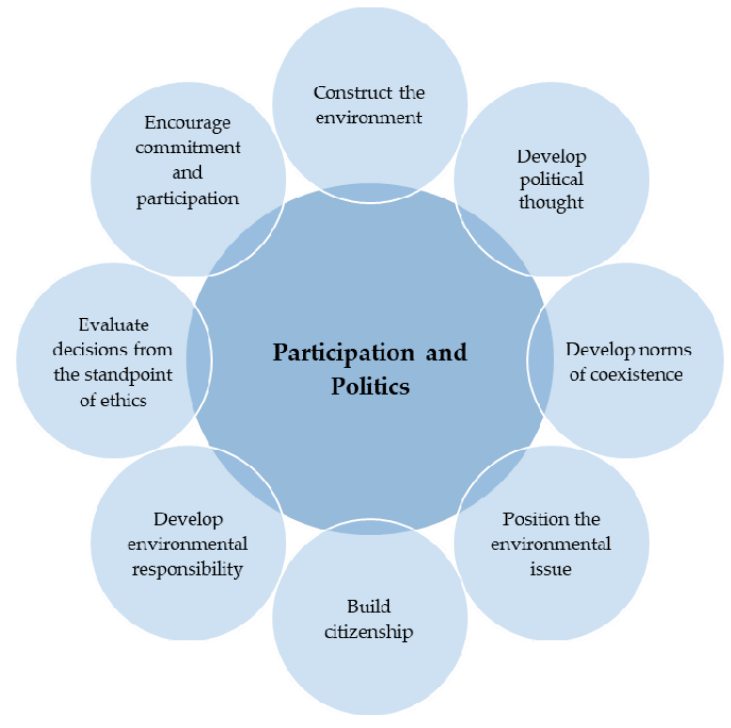

Figure 2. 'Participation and Politics'.

The "re-thinking education" category can be seen in the pedagogical practices of Inés, a natural science teacher, whose practices on the environment have the purpose of "improving education".

"We have to think about how caring for nature is related to education, which is very similar to the formal education that other people had before, but not everyone is receiving now."

This teacher constantly emphasizes the link between science and education. Her pedagogical practice focuses on how to improve the teaching and learning process, using a method which implies that connection with nature activates emotions, generates motivation and increases students' interest in scientific and ecological knowledge. Nature is, in this sense, an axis that motivates students as a means of covering more complex and tedious parts of the science curriculum. In contrast to the previous two categories, this teacher considers that the students are still at a stage prior to that of critical questions: "What do the girls know yet about being utopian?"

In this category, science-based education allows students to use knowledge about nature to understand "ecological problems". The extinction of living beings, for example, is framed as a problem "caused by bad political and economic decisions which arise because people are not able to choose between alternatives for their actions". According to this category, people are hampered by the failure of formal education today to equip them with the necessary scientific and ecological knowledge.

For this teacher, environmental education implies "re-thinking education from scratch". Appealing to both the functioning of nature and the emotions it provokes, she applies a practice that addresses both the purpose of care and the question of "how to teach better", proposing alternatives that favor the development of a didactic of the sciences.

The challenges that her pedagogical practice poses are fundamentally related to the co-construction of knowledge. Work in a collective vegetable garden constitutes an educational experience which she considers outside her subject area, but where the relationship between students and teacher is necessarily more flexible: 
"When I took on the vegetable garden workshop, I did not have much experience of planting and I told the girls 'Here we are going to explore together'."

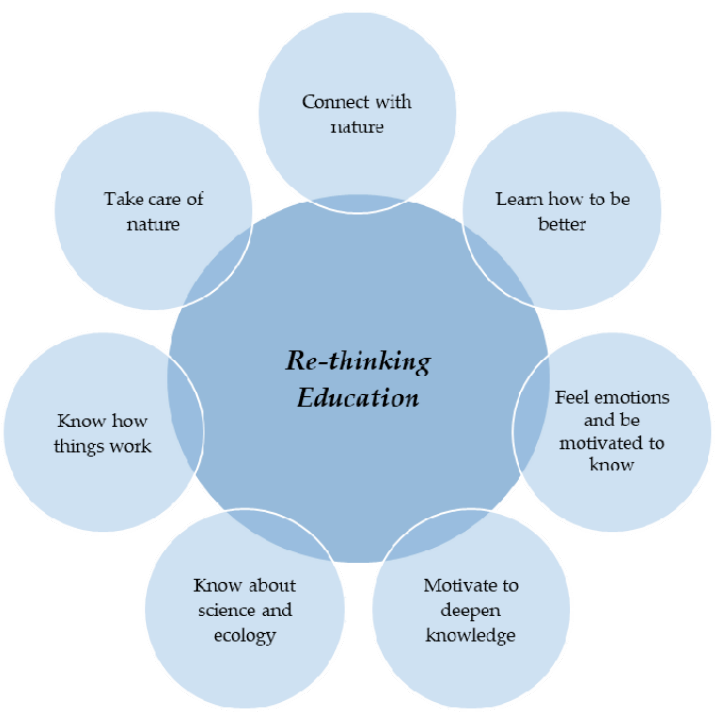

Figure 3. 'Re-thinking education'.

The table below provides a description of the three categories.

Table 1. Categories of long-term purposes and dimensions of approaches to the environment and teaching methods.

\begin{tabular}{|c|c|c|c|}
\hline & \multicolumn{3}{|c|}{ Dimensions } \\
\hline Long-Term Purposes & 'Connection and Consciousness' & 'Participation and Politics' & 'Re-thinking Education' \\
\hline $\begin{array}{l}\text { Approaches to the environment } \\
\text { Perspective of environmental } \\
\text { problems } \\
\text { What are they and how are they } \\
\text { resolved? }\end{array}$ & $\begin{array}{l}\text { Crisis of values that extends to the } \\
\text { economy and politics } \\
\text { Re-connect with principles of } \\
\text { nature }\end{array}$ & $\begin{array}{l}\text { Lack of adjustment of the } \\
\text { ways of life and interests of } \\
\text { different groups with respect } \\
\text { to the planet's limitations } \\
\text { Reflection and action }\end{array}$ & $\begin{array}{l}\text { Problems arising from } \\
\text { "lack of information" } \\
\text { Scientific information for } \\
\text { informed } \\
\text { decision-making }\end{array}$ \\
\hline $\begin{array}{l}\text { Causes of environmental } \\
\text { problems }\end{array}$ & $\begin{array}{l}\text { Crisis caused by human action } \\
\text { without consciousness of tie with } \\
\text { nature }\end{array}$ & $\begin{array}{l}\text { Indifference and lack of } \\
\text { empathy and participation }\end{array}$ & $\begin{array}{l}\text { Weaknesses in formal } \\
\text { education as regards } \\
\text { scientific and ecological } \\
\text { knowledge }\end{array}$ \\
\hline $\begin{array}{l}\text { Relation of humanity with the } \\
\text { natural world }\end{array}$ & $\begin{array}{l}\text { Principles of nature must guide } \\
\text { human action towards a paradigm } \\
\text { that is more reflexive and critical } \\
\text { with respect to nature and society }\end{array}$ & $\begin{array}{l}\text { Human decisions about the } \\
\text { planet have catastrophic } \\
\text { consequences for the } \\
\text { environment and society }\end{array}$ & $\begin{array}{l}\text { Important implications } \\
\text { of our actions for our } \\
\text { well-being and that of } \\
\text { ecosystems }\end{array}$ \\
\hline $\begin{array}{l}\text { Teaching methods Ethical and } \\
\text { political point of reference }\end{array}$ & $\begin{array}{l}\text { Importance of the development of } \\
\text { values and ethics for a change of } \\
\text { paradigm }\end{array}$ & Ethics and political criticism & $\begin{array}{l}\text { Ethics is key to the } \\
\text { process but politics is not } \\
\text { considered relevant at } \\
\text { this level of education }\end{array}$ \\
\hline Key subjects & Biology, ecology, and ethics & $\begin{array}{l}\text { Social sciences, ethics and } \\
\text { some elements of ecology }\end{array}$ & $\begin{array}{l}\text { Biology, ecology, and } \\
\text { ethics }\end{array}$ \\
\hline Principal teaching method & $\begin{array}{l}\text { Transition to co-construction } \\
\text { based on scientific knowledge and } \\
\text { experiential approach }\end{array}$ & $\begin{array}{l}\text { Debates and projects related } \\
\text { to topics agreed with } \\
\text { students }\end{array}$ & $\begin{array}{l}\text { Transition to } \\
\text { co-construction based on } \\
\text { scientific knowledge and } \\
\text { experiential approach }\end{array}$ \\
\hline Students & $\begin{array}{l}\text { Transition to active critics seeking } \\
\text { social change }\end{array}$ & $\begin{array}{l}\text { Active critics seeking social } \\
\text { change }\end{array}$ & $\begin{array}{l}\text { Passive in transition to } \\
\text { active co-construction }\end{array}$ \\
\hline Planning and democracy & $\begin{array}{l}\text { Central planning by teacher in } \\
\text { transition to co-construction }\end{array}$ & $\begin{array}{l}\text { Co-construction } \\
\text { Teachers and students } \\
\text { propose topics of interest for } \\
\text { debate }\end{array}$ & $\begin{array}{l}\text { Central planning by } \\
\text { teacher in transition to } \\
\text { co-construction }\end{array}$ \\
\hline $\begin{array}{l}\text { Goal/long-term objective. } \\
\text { What is the purpose of my } \\
\text { pedagogical practice for } \\
\text { environmental education? }\end{array}$ & $\begin{array}{l}\text { To re-connect the human being } \\
\text { with nature and foster } \\
\text { consciousness and change }\end{array}$ & $\begin{array}{l}\text { To incorporate } \\
\text { environmental issues to } \\
\text { foster students' participation } \\
\text { with a view to social change }\end{array}$ & Re-thinking education \\
\hline
\end{tabular}

Prepared by authors based on the dimensions of Sandell, et al. [66]. 
For analytical purposes, Table 1 shows different perspectives on the environment in relation to pedagogical practices. It highlights the transition from scientific approaches based on knowledge as an object to the co-construction of intersubjective knowledge geared to action in the social field.

\section{Discussion}

The categories identified in this article illustrate different pedagogical practices that appear to be influenced by the teachers' discipline of origin. The first category brings together natural science and philosophy teachers, emphasizing practices whose purpose is a paradigmatic change, based on the connection and potentialities of the relationship between human beings and nature that reveal injustices, which are also addressed as a purpose through environmental education. In the second category, social science teachers emphasize the decision-making process, explicitly targeting the political field as a means of addressing the changes that society requires, also based on an ideal of justice. The third category proposes a fundamental change in the way we conceive education and its role in the development of society, in this case through a change in the way of educating.

Although it is possible to identify the disciplines of origin behind each category, the analysis here focuses on "social change" as transversal to all three categories. In this way, it seeks to contribute to describing the dynamics between ecology and politics, which seem key for a contextualized interpretation of the proposed categories.

Despite the differences between categories, the purpose of the teachers' practices in both the first and second categories is social change, characterized by the need to overcome social inequalities. In this process, there is a strong emphasis on establishing links between the school and the community. In this sense, the teachers' socio-environmental concern about environmental issues at the local level is both a condition for and a result of the social change they promote.

The principle of justice as the axis of social change is central to the relationship between perspectives on the environment and education in the teachers' practices. We interpret "social change" as a purpose of educational practice that is not an end in itself, but the motivation for addressing a process that the teachers view as open-ended and, indeed, closely related to the challenges it poses. In this sense, the teachers' practices are ongoing democratic experiments, geared to the redefinition of existing political hegemonies, underpinned by the principles of equality and freedom, and taking into account the borders of the democratic order in strictly political terms [71,72].

In the Latin American context, Enrique Leff states that one of the characteristics of environmental thought is the process through which "ecology becomes political while, at the same time, politics becomes ecologized, but by dint of opening the systemic totality outside of nature to the symbolic and cultural order, to the realm of ethics and justice" [73] (p.20). Leff also argues that environmental education is the space where Latin American environmental thought "has nested with the greatest strength and clarity, where it reproduces and propagates" [74] (p. 13). Following Leff, we discuss the three categories presented here as examples of the bidirectional relationship between ecology and politics while, based on the teachers' practices, we interpret their underlying environmental approach.

From the teachers' standpoint, the interweaving of ecology and politics can be interpreted within this contextual framework, which emphasizes that "only the ecological crisis has the potential to destabilize any of the development frameworks that currently exist" [75] (p. 27). Ecology then is seen as a dimension that activates political processes and, specifically, as a space from which to seek to change modes of development. Interest in addressing environmental or ecological issues has its origin in a shared concern, which also implicitly or explicitly provides an answer to the question of how to live better in this particular context. This double relationship appears to be important for the teachers, who raise critical questions in the face of which action based on intersubjective community knowledge is highlighted for the importance of its contextual value.

In the case of configuration of the "environmental problem", teachers are influenced by a series of stances that can be summarized as part of the framework of "Latin American Environmental Thought" and are characterized by their analysis of the region's situation of dependency. In Latin 
America, political ecology emphasizes the social and environmental consequences of extractivism and post-extractivism and, along with the regional approach to environmental justice, provides visions that analyze production processes in light of the specific social relationships in which they are embedded [76,77]. Such analysis necessarily implies taking a position on inequalities in the distribution of the environmental costs of these models. These positions form part of teachers' meaning-making process regarding their perspective on social change on the environment.

Highlighting the differences that exist with some conservationist positions in the North, Alier [78] discusses the "ecology of the poor" as a characteristic of specific social relations with the environment in Latin America where conservation is closely related to communities' direct dependence on natural resources. The emphasis on the social and environmental consequences of extractivism and the unfair distribution of social and environmental costs among the world's population frames the environmental outlook in different terms, ranging from macroeconomic analysis of the economic cycles to the consequences for daily practices. In light of this, it is possible to interpret teachers' environmental education practices as actively related to critical language and practice at the community and local level. Teachers' perspective on the environment coexists with different versions of the environment as "problem", "natural resources", and "nature", but highlights the environment as a "community project". This latter perspective is important in the Latin American context because it makes visible a collective relationship with the environment, positioning the environment as a political concern and focus of critical analysis and as the place of community commitment to a project and its collective construction [79] (p. 13). However, this perspective does not exclude other possible perspectives, but rather highlights the community axis and once again links politics and ecology.

When teachers see the environment as a community issue, the possibility of a co-relation with critical pedagogy becomes relevant because this framework to which some explicitly adhere also enables them to experience the possibility of a radical and emplaced critical theory. The critical pedagogy approach seeks to transcend the field of the merely "pedagogical" and places the teacher-student relationship in a particular cultural, social, economic, and political context, which guides the educational proposal in the creation of language appropriate to its own realities of domination. Consequently, Paulo Freire's proposal does not begin and end with the logic of political, economic, and cultural reproduction typical of traditional education, but starts with the production process [80]. The influence of critical pedagogy and its emphasis on practice seem key as a reference for teachers in the transition from teacher-centered pedagogies to others that emphasize the co-construction of knowledge. The teachers in the "participation and politics" category emphasize that the issues to be addressed-"environmental issues"- should be proposed and discussed by the students themselves and, in this and the other categories, the transition is reflected in the challenges assumed by the teachers and the acceptance and valuing of uncertainty as an integral part of the intersubjective co-production of knowledge.

These challenges are key for the "re-thinking education" category where "exploring together" is explicitly recognized as a transgressive element of the traditional scientific logic of knowledge transmission. In this category, the proposed change does not imply overcoming inequalities-at least, not in the educational phase to which it alludes-but, instead, focuses on transforming current education into an integral educational process through which to foster the scientific rationality required to act in the world in a correct way. This option is close to the perspective of "environment as nature" $[67,79]$ in the sense that it views science as a heuristic of nature that has the potential to guide us towards a reliable rationality as a means of living better. This vision also has links to the selective fact-based tradition as well as the normative tradition proposed by Öhman [27] and Sandell et al. [66] in the Swedish context, under which teaching and planning methods center on the teacher. Despite these characteristics, which seem to undermine the pluralist nature of this project, the "re-thinking education" category is also radical in that it seeks to explore concrete alternatives to the current educational model and "re-think education from scratch" in a bid to build a new educational project that transforms society as a whole. 
Through their practices, teachers demonstrate their resistance to traditional norms and canons. Across all the categories, teachers' decision to address environmental issues in the school represents a rejection of the closure of possibilities of action in favor of openness to the possible new utopias it can achieve.

Reinforcing its potential and relevance, de Sousa Santos [81] defines utopia as "the opposition of the imagination to the necessity of what exists, only because, in its name, something radically better exists for which it is worth fighting and to which humanity has the right" (p. 25). In line with this, we argue that transgression in practices opens the way to intersubjective meaning-making, which is a condition for a subjectivity that "distances itself from rest and comfort, towards a sense of direction" (p. 109). This does not imply an unrealizable utopia, but the possibility and the right to think about something radically better. Utopian thinking, which seems discredited and obsolete today, despite being urgently needed [81], appears key in the teachers' meaning-making and, at the same time, serves as a space where the link between their perspectives on education and the environment acquire meaning.

\section{Final Comments}

The efforts involved in addressing the environment as part of the construction of a social project from the educational field imply transcending the barriers of school and traditional schooling in pursuit of projects that go beyond current objectives. In this practice, teachers insist on the need to overcome hierarchies, to question power relations in the construction of knowledge, and to connect the inside and outside of the school. The links they establish between education and the environment create possibilities of transgression and represent a new space in which they project their purposes for change. The environment offers a new means of addressing the common project, which once again places the axis in the community sphere and represents the "radically different" [36] as opposed to the traditional structure of school and education and the neoliberal project with its emphasis on the individualization of responsibilities (social, environmental, and other).

Although the intention of this article is not to echo the "tired conversation" between environmental education and ESD [82], the practices we found lead us to reflect on their differences within the framework of meaning-making in different contexts. As we have proposed in a recent paper, the co-construction of knowledge through community experience can be described in terms of "weaving" a network of different levels of knowledge and action: subjective, intersubjective in the classroom, community, and operational, which are co-implicated in a dynamic from which meaning emerges [2]. Under this logic, the operational level of environmental policy that defines environmental education as an "instrument of environmental management" [55] (p.15) and the educational proposals of the ESD policy are dynamically related to the teachers' meaning-making, but are not necessarily axes of meaning of their own pedagogical practices.

Teachers' practices are pedagogical alternatives to the normative "problems and solutions" to the environmental crisis configured through their cultural references. Teachers are actively proposing contextualized perspectives for the purpose of emergence of collective meaning and action, linking environment and education and, thereby, pushing out established limits and transgressing normalized forms. We take the view that these forms of trangression go beyond the frameworks established by "transformative learning" [83] approaches, which emphasize the processes at the individual level. These transgressive practices, which have meaning for the teachers in terms of taking a position in the face of the current crisis, provide space for the development of emplaced educational projects from which new possibilities for community action emerge, as well as new futures.

Author Contributions: Conceptualization, A.C.-M. and L.F.-G.; methodology, A.C.-M.; software, A.C.-M.; investigation, A.C.-M. and L.F.-G.; writing—original draft, A.C.-M.; writing—review and editing, L.F.-G.; project administration, L.F.-G.; funding acquisition, L.F.-G.

Funding: This research was funded by VRI-UC Project 171120012. Flores, Luis M. (2017-2018) “Complex knowledge structures in Geography and Biological Sciences. Toward the formulation of an interdisciplinary program in sustainable development education." 
Acknowledgments: We would like to thank the teachers who participated in this research for their dedication to their work and honest and disinterested contribution. We also appreciate the important contributions and generosity of Per Sund, and the path already taken by the research group "Studies of Meaning-making in Educational Discourses" (SMED) at Örebro University and Uppsala University. We would also like to thank the guest editors of this Special Issue for providing the opportunity to discuss counterhegemonic perspectives on education and environment.

Conflicts of Interest: The authors declare no conflict of interest.

\section{References}

1. Morin, E. Los Siete Saberes Necesarios Para La Educación Del Futuro; Organización de las Naciones Unidas para la Educación, la Ciencia y la Cultura: Paris, France, 1999.

2. Condeza-Marmentini, A.; Flores-González, L.M. Configurations and meanings of environmental knowledge: Transitions from the subjective experience of students towards the intersubjective experience of us. Sustainability 2019, 11, 3050. [CrossRef]

3. Orr, D. Earth in Mind: On Education, Environment, and the Human Prospect; Island Press: Washington, DC, USA, 1994.

4. Sund, P.; Lysgaard, J.G. Reclaim “Education” in Environmental and Sustainability Education Research. Sustainability 2013, 5, 1598-1616. [CrossRef]

5. Jickling, B.; Wals, A.E.J. Normative Dimensions of Environmental Education Research Conceptions of Education and Environmental Ethics; AERA: New York, NY, USA, 2013; pp. 69-73.

6. Le Grange, L. Why We Need a Language of (Environmental) Education. In International Handbook of Research on Environmental Education; Stevenson, R.B., Brody, M., Dillon, J., Wals, A.E.J., Eds.; AERA: New York, NY, USA, 2013; pp. 108-114.

7. United Nations. Transforming our World: The 2030 Agenda for Sustainable Development; Assambly, G., Ed.; United Nations: New York, NY, USA, 2015.

8. Greenwood, D.A. A Critical Theory of Place-Conscious Education. In International Handbook of Research on Environmental Education; Stevenson, R.B., Brody, M., Dillon, J., Wals, A.E.J., Eds.; AERA: New York, NY, USA; London, UK, 2013; pp. 93-100.

9. Greenwood, D.A. Why Place Matters Environment, Culture, and Education. In Handbook of Research in the Social Foundations of Education; Routledge: London, UK, 2011; pp. 632-640.

10. Greenwood, D.A. A critical pedagogy of place: From gridlock to parallax. Environ. Educ. Res. 2008, 14, 336-348. [CrossRef]

11. Greenwood, D.A. Foundations of Place: A Multidisciplinary Framework for Place-Conscious Education. Am. Educ. Res. J. 2003, 4, 619-654.

12. McKenzie, M. The places of pedagogy: Or, what we can do with culture through intersubjective experiences. Environ. Educ. Res. 2008, 14, 361-373. [CrossRef]

13. Tuck, E.; McKenzie, M.; McCoy, K. Land education: Indigenous, post-colonial, and decolonizing perspective on place and environmental education research. Environ. Educ. Res. 2014, 20, 1-23. [CrossRef]

14. Zeyer, A.; Kelsey, E. Environmental Education in a Cultural Context. In International Handbook of Research on Environmental Education; Stevenson, R.B., Brody, M., Dillon, J., Wals, A.E.J., Eds.; AERA: New York, NY, USA, 2013; pp. 206-212.

15. Tilbury, D.M.; Mulà, I. A Review of Education for Sustainable Development Policies from a Cultural Diversity and Intercultural Dialogue Perspective: Identifying Opportunities for Future Action; UNESCO: Paris, France, 2008.

16. Nurse, K. Culture as the fourth pillar of sustainable development. In Proceedings of the Commonwealth Heads of Government Meeting, London, UK, 16-20 April 2018.

17. Gough, N. Thinking Globally in Environmental Education: Implications for Internationalizing Curriculum Inquiry. In International Handbook of Curriculum, Pinar, W.F., Ed.; Lawrence Erlbaum Associates: Mahwah, NJ, USA; London, UK, 2003; pp. 53-72.

18. González-Gaudiano, E.J.; Lorenzetti, L. Trends, Junctures, and Disjunctures in Latin American Environmental Education Research. In International Handbook of Research on Environmental Education; Stevenson, R.B., Brody, M., Dillon, J., Wals, A.E.J., Eds.; AERA: New York, NY, USA; London, UK, 2013; pp. 171-177.

19. González-Gaudiano, E.J. Schooling and environment in Latin America in the third millennium. Environ. Educ. Res. 2007, 13, 155-169. [CrossRef] 
20. Lotz-Sisitka, H.; Wals, A.B.J.; Kronlid, D.; McGarry, D. Transformative, transgressive social learning: Rethinking higher education pedagogy in times of systemic global dysfunction. Curr. Opin. Environ. Sustain. 2015, 16, 73-80. [CrossRef]

21. Lotz-Sisitka, H. Reviewing strategies in/for ESD policy engagement: Agency reclaimed. J. Environ. Educ. 2016, 47, 91-103. [CrossRef]

22. Biesta, G.J.J. The Beautiful Risk of Education; Paradigm: Boulder, CO, USA; London, UK, 2014.

23. Biesta, G.J.J. Against learning. Reclaiming a language for education in an age of learning. Nord. Pedagog. 2005, 25, 54-66.

24. Biesta, G.J.J. Good Education in an Age of Measurement: Ethics, Politics, Democracy; Routledge: New York, NY, USA, 2016.

25. Biesta, G.J.J. Good education in an age of measurement: On the need to reconnect with the question of purpose in education. Educ. Assess. Eval. Account. 2009, 21, 33-46. [CrossRef]

26. Hart, P. Teachers' Thinking in Environmental Education: Consciousenes and Responsability; Peter Lang: New York, NY, USA, 2003; p. 260.

27. Öhman, J. Moral Perspectives in Selective Traditions of Environmental Education-Conditions for environmental moral meaning-making and students' constitution as democratic citizens. In Learning to Change Our World? Swedish Research on Education \& Sustainable Development; Wickenberg, P.E.A., Ed.; Studentlitteratur: Lund, Sweden, 2004; pp. 21-32.

28. Sund, P.; Wickman, P.O. Teachers' objects of responsibility: Something to care about in education for sustainable development? Environ. Educ. Res. 2008, 14, 145-163. [CrossRef]

29. Sund, P.; Wickman, P.O. Socialization content in schools and education for sustainable development-I. A study of teachers' selective traditions. Environ. Educ. Res. 2011, 17, 599. [CrossRef]

30. Nikel, J. Making sense of education 'responsibly': Findings from a study of student teachers' understanding(s) of education, sustainable development and Education for Sustainable Development. Environ. Educ. Res. 2007, 13, 545-564. [CrossRef]

31. Stevenson, R.B. Schooling and environmental education: Contradictions in purpose and practice. Environ. Educ. Res. 2007, 13, 353-360. [CrossRef]

32. Hart, P.; Nolan, K. A critical analysis of research in enviromental education. Stud. Sci. Educ. 1999, 34, 1-69. [CrossRef]

33. Hwang, S. Teachers' environmental education as creating cracks and ruptures in school education: A narrative inquiry and an analysis of teacher rhetoric. Environ. Educ. Res. 2009, 15, 697-714. [CrossRef]

34. Castoriadis, C. El Campo de lo social histórico. Estud. Filos. -Hist. -Let. 1986, 4, 7-25. [CrossRef]

35. Biesta, G.J.J. Freeing Teaching from Learning: Opening Up Existential Possibilities in Educational Relationships. Stud. Phil. Educ. 2015, 34, 229-243. [CrossRef]

36. Scott, W.; Gough, S. Sustainable Development and Learning: Framing the Issues; RoutledgeFalmer: London, UK, 2003.

37. Cross, R.T. Teachers' Views about What to do about Sustainable Development. Environ. Educ. Res. 1998, 4, 41-52. [CrossRef]

38. Corney, G.; Reid, A. Student teachers' learning about subject matter and pedagogy in education for sustainable development. Environ. Educ. Res. 2007, 13, 33-54. [CrossRef]

39. Summers, M.; Corney, G.; Childs, A. Teaching Sustainable Development in Primary Schools: An empirical study of issues for teachers. Environ. Educ. Res. 2003, 9, 327-340. [CrossRef]

40. Borg, C.; Gericke, N.; Hoglund, H.O.; Bergman, E. The barriers encountered by teachers implementing education for sustainable development: Discipline bound differences and teaching traditions. Res. Sci. Technol. Educ. 2012, 30, 185-207. [CrossRef]

41. Borg, C.; Gericke, N.; Hoglund, H.O.; Bergman, E. Subject- and experience-bound differences in teachers' conceptual understanding of sustainable development. Environ. Educ. Res. 2014, 20, 526-551. [CrossRef]

42. Aarnio-Linnanvuori, E. How do teachers perceive environmental responsibility? Environ. Educ. Res. 2019, 25, 46-61. [CrossRef]

43. Hasslöf, H.; Malmberg, C. Critical thinking as room for subjectification in Education for Sustainable Development. Environ. Educ. Res. 2015, 21, 239-255. [CrossRef]

44. Yang, G.; Lam, C.-C.; Wong, N.-Y. Developing an Instrument for Identifying Secondary Teachers' Beliefs About Education for Sustainable Development in China. J. Environ. Educ. 2010, 41, 195-207. [CrossRef] 
45. Raselimo, M.; Wilmot, D. Geography teachers' interpretation of a curriculum reform initiative: The case of the Lesotho Environmental Education Support Project (LEESP). S. Afr. J. Educ. 2013, 33. [CrossRef]

46. Watson, K.; Halse, C.M. Environmental attitudes of pre-service teachers: A conceptual and methodological dilemma in cross-cultural data collection. Asia Pac. Educ. Rev. 2005, 6, 59-71. [CrossRef]

47. Waktola, D.K. Challenges and opportunities in mainstreaming environmental education into the curricula of teachers' colleges in Ethiopia. Environ. Educ. Res. 2009, 15, 589-605. [CrossRef]

48. Ketlhoilwe, M.J. Governmentality in environmental education policy discourses: A qualitative study of teachers in Botswana. Int. Res. Geogr. Environ. Educ. 2013, 22, 291-302. [CrossRef]

49. Ross, H. Negotiating managerialism: Professional recognition and teachers of sustainable development education. Environ. Educ. Res. 2015, 21, 403-416. [CrossRef]

50. González-Gaudiano, E.J. Otra lectura a la historia de la educación ambiental en América Latina y el Caribe. Tópicos En Educ. Ambient. 1999, 1, 9-26.

51. Muñoz-Pedreros, A. La educación ambiental en Chile, una tarea aún pendiente. Ambiente Soc. 2014, 17, 177-198. [CrossRef]

52. Squella, M.P. Environmental Education to Environmental Sustainability. Educ. Phil. 2001, 33, $217-230$. [CrossRef]

53. Shirley, D.; Fernández, M.B.; Ossa Parra, M.; Berger, A.; Borba, G. The Fourth Way of Leadership and Change in Latin America: Prospects for Chile, Colombia, and Brazil. Pensam. Educ. Rev. De Investig. Educ. Latinoam. 2013, 50, 5-28. [CrossRef]

54. Carrasco, A. Mecanismos performativos de la institucionalidad educativa en Chile: Pasos hacia un nuevo sujeto cultural. Obs. Cult. 2013, 15, 4-10.

55. MMA. Bases Generales del Medio Ambiente; Ministerio de Medio Ambiente Chile: Santiago, Chile, 1993.

56. Gonzáles-Muñoz, M.C. Principales tendencias y modelos de la Educación Ambiental en el sistema escolar. Rev. Iberoam. De Educ. -Educ. Ambient. Teoría Y Práctica 1996, 11, 13-68.

57. MMA. Diagnóstico de Compromiso en Sustentabilidad de las Universidades Chilenas; Ministerio de Medio Ambiente Chile: Santiago, Chile, 2017.

58. Merleau-Ponty, M. Phénoménologie de la Perception; Gallimard, É., Ed.; Librairie Gallimard: Paris, France, 1945.

59. Varela, F.J. El Fenómeno de la Vida; Dolmen: Santiago, Chile, 2000.

60. Biesta, G.J.J.; Burbules, N. Pragmatism and Educational Research; Rowman and Littlefield: Lanham, MD, USA, 2003.

61. Dewey, J. Experience and Nature. The Later Works of John Dewey; Boydston, J.A., Ed.; Southern Illinois University Press: Carbondale, IL, USA; Edwardsville, IL, USA, 1988; Volume 1.

62. Dewey, J.; Bentley, A. Knowing and the known. In John Dewey: The Later Works, 1949-1952; Boydston, J.A., Ed.; SIU Press: Carbondale, IL, USA, 1991; Volume 16.

63. Dewey, J. Art as Experience; Perigee Books: New York, NY, USA, 1980.

64. Varela, F.J.; Thompson, E.; Rosh, E. The Embodied Mind. Cognitive Science and Human Experience; MIT: Cambridge, MA, USA, 1991.

65. Bertrand, Y.; Valois, P. École et Sociétés; Éditions Agence d'Arc: Montreal, QC, Canada, 1992.

66. Sandell, K.; Öhman, J.; Östman, L. Education for Sustainable Development: Nature, School and Democracy; Studentlitteratur: Lund, Sweden, 2005.

67. Sauvé, L. Una cartografía de corrientes en Educación Ambiental. In A Pesquisa em Educação Ambiental: Cartografias de uma Identidade Narrativa em Formação; Sato, M., Carvalho, I., Eds.; Artmed: Porto Alegre, Brazil, 2004.

68. Sauvé, L. Exploración de la Diversidad de Conceptos y de Prácticas en la Educación Relativa al Ambiente. Seminario Internacional: La Dimensión Ambiental y la Escuela, Bogotá, Colombia. Available online: http://koha.ideam.gov.co/cgi-bin/koha/opac-detail.pl?biblionumber=40541\&shelfbrowse_ itemnumber $=39650$ (accessed on 26 October 2019).

69. Sterling, S. Higher Education, Sustainability, and the role of Systemic Learning. In Higher Education and the Challenge of Sustainability; Corcoran, P.B., Wals, A.E.J., Eds.; Kluwer Academic Publishers: Dordrecht, The Netherlands, 2004; pp. 49-70.

70. Kolb, D. Experiential Learning as the Science of Learning and Development; Prentice Hall: Englewood Cliffs, NJ, USA, 1984.

71. Mouffe, C. The Return of the Political; Verso: London, UK; New York, NY, USA, 1993. 
72. Mouffe, C. On the Political; Routledge: New York, NY, USA; London, UK, 2005.

73. Leff, E. La ecología política en América Latina. Un campo en construcción. Polis Rev. Académica Univ. Boliv. 2003, 1, 125-145. [CrossRef]

74. Leff, E. Pensamiento Ambiental Latinoamericano: Patrimonio de un Saber para la Sustentabilidad. In Proceedings of the VI Congreso Iberoamericano de Educación Ambiental, San Clemente de Tuyú, Argentina, 16-19 September 2009.

75. Escobar, A. Encountering Development. The Making and Unmaking of the Third World; Priceton University Press: Princeton, NJ, USA, 2012.

76. Gudynas, E. Desarrollo, extractivismo y postextractivismo. In Proceedings of the Seminario Andino: Transiciones, postextractivismo y alternativas al extractivismo en los países andinos, Lima, Peru, 16-18 May 2002.

77. Gudynas, E. Diez tesis urgentes sobre el nuevo extractivismo. Contextos y demandas bajo el progresismo sudamericano actual. In Extractivismo, Politica y Sociedad; Centro Andino de Acción Popular (CAAP) y Centro Latino Americano de Ecología Social (CLAES): Quito, Ecuador, 2009; pp. 187-225.

78. Alier, J.M. El Ecologismo de los Pobres. Conflictos Ambientales y Lenguajes de Valoración, 3rd ed.; Icaria: Barcelona, Spain, 2005.

79. Sauvé, L. Environmental Education and Sustainable Development: A Further Appraisal. Can. J. Environ. Educ. 1996, 1, 7-34.

80. Giroux, H.A. Introduction. In La Naturaleza Politica de la Educación: Cultura, Poder y Liberación; Paidos: Barcelona, Spain, 1990.

81. De Sousa Santos, B. Construyendo las Epistemologías del Sur. Antología Escencial; Consejo Latinoamericano de Ciencias Sociales: Buenos Aires, Argentina, 2018.

82. Sauvé, L.; Berryman, T. Language and Discourses of Education, Environment and Sustainable Development. In International Handbook of Research on Environmental Education; Stevenson, R.B., Brody, M., Dillon, J., Wals, A.E.J., Eds.; AERA: New York, NY, USA, 2013; pp. 133-146.

83. Mezirow, J. Transformative Dimensions of Adult Learning; Jossey-Bass: San Francisco, CA, USA, 1991.

(C) 2019 by the authors. Licensee MDPI, Basel, Switzerland. This article is an open access article distributed under the terms and conditions of the Creative Commons Attribution (CC BY) license (http://creativecommons.org/licenses/by/4.0/). 